\title{
Interepithelial lymphocytes of the rat submandibular gland
}

\author{
Yasunori Takeda and Akira Fujimura* \\ Department of Oral Pathology and Oral Anatomy I*, School of Dentistry, \\ Iwate Medical University, Uchimaru 19-1, Morioka, Iwate 020, Japan
}

[Accepted for publication: July 17, 1985]

Key words : Interepithelial lymphocytes / salivary gland

\begin{abstract}
The distribution of interepithelial cells in the rat submandibular gland was investigated histologically and ultrastructurally. All the interepithelial cells were small lymphocytes with a smooth or shallow-indented nuclear outline, and were located below the level of the epithelial cell nuclei of acini and ducts. No other cells such as Langerhans cells or cerebriform cells, such as are commonly found in stratified squamous epithelia, were detected. A mean of 6.7 interepithelial lymphocytes per 1,000 salivary gland epithelial cells was found : 7.1 in acini, 4.6 in intercalated ducts, 6.7 in gran: ular and striated ducts, and 8.3 in excretory ducts.
\end{abstract}

\section{Introduction}

Epithelia of external and internal surfaces of the mammalian body commonly include cells at various levels that differ from the majority of epithelial cells in possessing a clear halo around the nucleus. Such 'clear cells' are designated interepithelial or intraepithelial cells, and are variously classified as melanocytes, Langerhans cells, Merkel cells, lymphocytes, or others. Of these, an important function as a first immunological barrier has been ascribed to interepithelial lymphocytes which are distributed in both single-layered epithelia and stratified squamous epithelia, and some regions of the epithelia could probably have a function in the maturation and instruction of the lymphocytes equivalent to the function of the bursa Fabricii in birds.

The distribution and frequency of interepithelial lymphocytes occurring in normal condition have been studied in the intestinal tracts $^{1)}$, epidermis ${ }^{2,3)}$, and oral mucosa ${ }^{4-7)}$. However, there are no reports of such cells in the salivary gland epithelia. The purpose of the present paper is to report the distribution and frequency of interepithelial lymphocytes in the submandibular gland of the rat.

\section{Materials and Methods}

10 male Wistar rats weighing 250 to $300 \mathrm{~g}$ were used. The animals were maintained under conventional condition with exogenous antigen exposure.

Both right and left submandibular glands were fixed in 10 per cent neutral-buffered formalin immediately after sacrifice by ether anesthesia, embedded in paraffin, and $4 \mu$ thin sections were stained with hematoxylin and eosin, periodic acid-Shiff and a silver impregnation method (Watanabe's method). In addition activity of N-AS-D-chloroacetate esterase was examined.

Specimens for ultrastructural investigation were fixed immediately in 4.0 per cent glutaraldehyde by immersion and post-fixed in 2.0 per cent osmium tetroxide, dehydrated, and embedded in resin. Semithin sections were stained with toluidine blue. Then the ultrathin sections were cut, stained with uranyl acetate and lead citrate, and examined under an Akashi LEM-2000 ultramicroscope.

Under the ultramicroscope, all recognizable interepithelial mononuclear cells were counted in relation to the number of salivary gland epithelial cells, and numbers of the interepithelial mononuclear cells per 1,000 salivary gland epithelial cells were computed 
in acini, intercalated, granular and striated, and excretory ducts.

\section{Results}

Light microscopy :

The common light microscopic findings of interepithelial mononuclear cells stained with hematoxylin and eosin were chromatin-dense and small round nuclei surrounded by clear halo, and indistinct cytoplasm (Figs. 1 and 2). The most of these interepithelial mononuclear cells were located below the level of the epithelial cell nuclei, and they occurred singly in both acini and ducts. Although a few lymphocytes and plasma cells were scattered in interacinal and periductal fibrous connective tissue stroma in part, they were not noted in the fibrous connective tissue stroma adjecent to the epithelial regions with interepithelial monouclear cells (Figs. 1 and 2). No cells with activity of N-AS-D-chloroacetate esterase were found in either epithelia and fibrous connective tissue stroma.

Ultrastructural finding :

Ultrastructurally, 142 interepithelial mono- nuclear cells in the rat submandibular salivary gland epithelia were documented. All of the interepithelial mononuclear cells in the rat submandibular salivary gland epithelia were small lymphocytes, and no other cells such as Langerhans cells and Merkel cells distributed normally in the stratified squamous epithelia were found. These interepithelial lymphocytes were round to oval in shape with smooth cell-outlines, 4.0 to $6.0 \mu \mathrm{m}$ in apico-basal diameter, and located in basal regions of the acini and ducts (Figs. 3 and 4). The cytoplasm of lymphorytes was sparse, containing free ribosomes, a few mitochondria and endoplasmic reticulum. The nuclei of lymplocytes were spherical in shape and contained abundant heterochromation, but nucleoli were inconspicuous. The margin of these nuclei were smooth (Fig. 3) or with shallow-indentations (Fig. 4). However, lymphocytes with deeply indented nuclei called 'cerebriform cells' were not found.

Quantitative evaluation:

The result of the count of interepithelial lymphocytes under the ultramicroscope in the

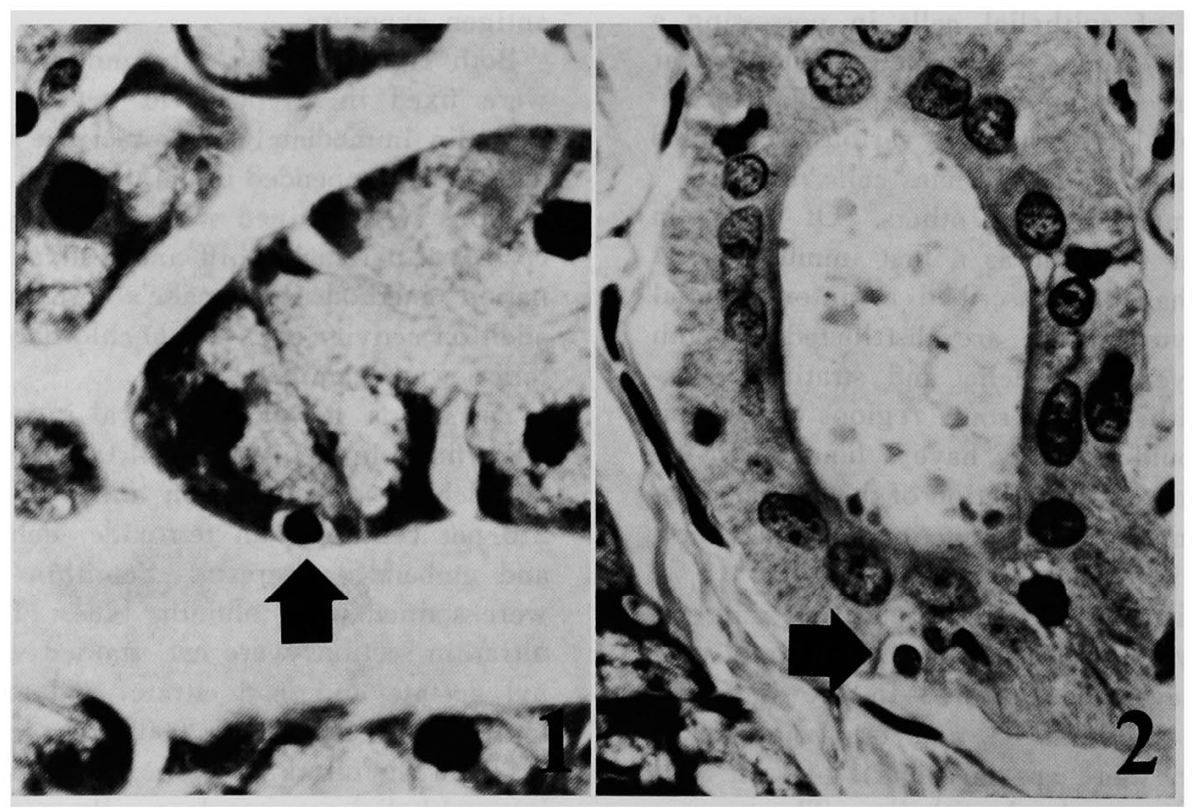

Figs. 1 and 2. Light photomicrographs of interepithelial mononuclear cells (arrows) in acinus (1) and excretory duct (2) of rat submandibular salivary gland. No mononuclear cells or other inflammatory cells in the fibrous connective tissue stroma. Hematoxylin and eosin, Fig. $1 \times 400$ and Fig. $2 \times 350$. 

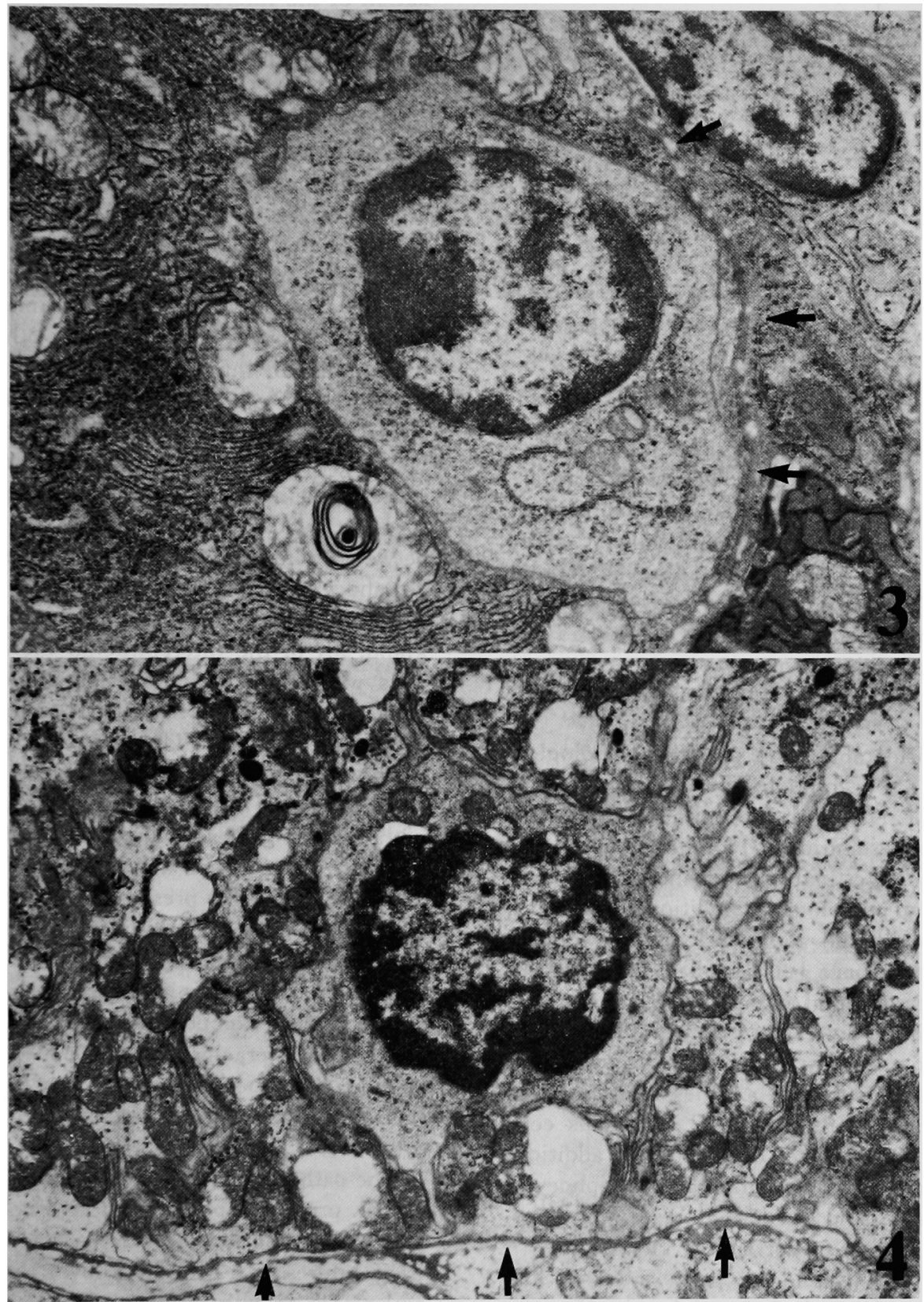

Figs. 3 and 4. Photographs showing the ultrastructure of interepithelial lymphocytes in the acinus (3) and striated duct (4) of rat submandibular salivary gland. Fig. 3 shows small lymphocyte with a smooth nuclear outline, and Fig. 4 shows small lymphocytes with slight nuclear indentations. Arrows indicate basal lamina. Fig. $3 \times 13,200$ and Fig. $4 \times 8,720$. 


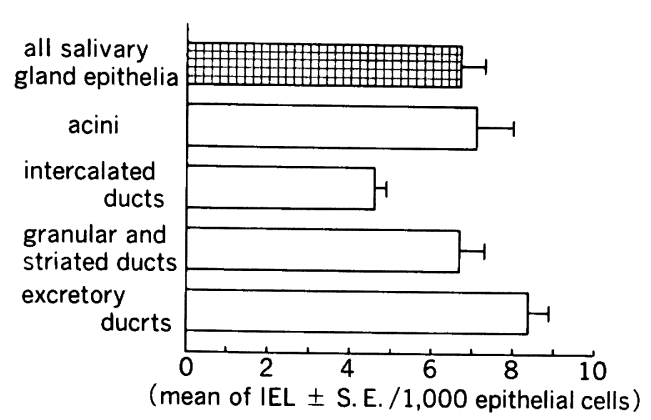

Fig. 5. Quantitative distribution of interepithelial lymphocytes (IEL) in the rat submandibular salivary gland epithelia.

rat submandibular gland acini, intercalated, granular and striated, and excretory ducts are shown in Fig. 5. A mean of 6.7 interepithelial lymphocytes per 1,000 salivary gland epithelial cells is found in rat submandibular gland : 7.1 in acini, 4.6 in intercalated duct, 6.7 in granular and striated ducts, and 8.3 in excretory duct.

\section{Discussion}

A considerable amount of morphological research has been reported on the intercellular mononuclear cells of the epithelia, and most of such investigations so far have concentrated on the intestinal mucosa and epidermis in normal and pathological conditions ${ }^{1-3)}$. Recently, interepithelial mononuclear cells of the oral mucosa have been studied in detail ${ }^{4-7)}$. The interepithelial mononuclear cell population of single-layered epithelia is almost completely composed of lymphocytes, and in stratified squamous epithelia other interepithelial mononuclear cells such as Langerhans cells and Merkel cells are distributed in addition. Furthermore, interepithelial lymphocytes have been found in normal visceral organs, i.e., in kidney reported by Bohle et al. ${ }^{8)}$ and in thyroid gland reported by Toujas and Guelf ${ }^{9)}$. Although their origin, significance, function and fate are still known only in fragments, it is thought that one of the important roles of interepithelial mononuclear cells, especially lymphocytes and Langerhans cells, is to form a first immunological barrier. In the oral mucosa, Burkhardt et al. ${ }^{6)}$ and Bos and Burkhardt ${ }^{7)}$ have reported an interesting quantitative and qualitative exami- nation of the interepithelial mononuclear cell population in mice under different antigen exposure, with special attention to the lym. phocytes and Langerhans cells. They say that interepithelial lymphocytes must be considered an integral component of the oral epithelium, since interepithelial lymphocytes are noted in germfree animals, and since interepithelial lymphocytes do not show a significant increase in specific pathogen-free or conventionally maintained animals compared to germfree ones. On the other hand, the number of interepithelial lymphocytes in the intestinal mucosa shows a significant decrease in germfree animals compared to conventionalized one ${ }^{10)}$, but they are not absent in germfree animals ${ }^{11-13)}$. Then there seem to be a fundamental difference in function between intestinal and oral interepithelial lymphocytes ${ }^{7}$.

In the present study of rat submandibular gland, all of the interepithelial mononuclear cells were small lymphocytes, and no other cells distributed in stratified squamous epithelia were found. The nuclei of these interepithelial lymphocytes were round in shape with or without shallow indentation, but cells with deeply indented nuclei called 'cerebriform cells' were not found. Although animals used in the present examination were maintained conventinally, the appearance of interepithelial lymphocytes might be not the expression of a subclinical inflammation, since neither mono- nor poly-nuclear cells infiltrated in the interacinar and periductal fibrous connective tissue stroma adjacent to the epithelial regions with interepithelial lymphocytes.

The pathological and biological significance of the present report of interepithelial lymphocytes in normal salivary gland epithelia is of interest. It is well known that during embryonic growth salivary glands are closely associated with the lymphoid tissue. Such a relation between salivary gland epithelia and lymphoid tissues may give rise to some salivary gland lesions such as benign lymphoepithelial lesions, Warthin's tumor, lymphoepithelial cyst, etc.

This study was supported in part by Grant in 
抄録：唾液腺における上皮内リンパ球の分布を詳細に検索した報告は未だない。そこで筆者はラット頒下腺 を用いて超微構造的にこの点について検討を試みた。

検索に江体重 $250 \sim 300 \mathrm{~g}$ の雄 Wistar ラットを用い, 嚬下腺を摘出後直ちに固定し, 通法の如く超薄切 片を作製した。超微構造的に上皮内リンパ球の形態を観察するとともに，唾液腺上皮を腺房部，介在部，顆 粒管および線条部，主導管の 4 部位に分けて各部位における上皮細胞 1,000 個に対する上皮内リンハ球の数 を算出した。

今回の検索で超微構造的に 142 個の上皮内リンパ球が観察された。これら上皮内リンパ球のすべては小リ ンパ球であり，球状の核を有し，胞体内には遊離リボゾームの他にはごくわずかのミトコンドリアと粗面小 胞体をみるにすぎなかった。また，核に梁い切れ込みを有するいわゆる cerebriform 型とよばれるリンハ球 はみられなかった。なお，唾液腺上皮内に特殊な胞体内顆粒や細成間結合装置を有する上皮内細胞は認めら れなかった。

上皮内リンパ球の唾液腺上皮各部位における分布は上皮細胞 1,000 個に対して腺房部では 7.1 個, 介在部 では 4.6 個, 顆粒管と線条部では 6.7 個, 主導管では 8.3 個であった。

\section{References}

1) Otto, H. F.: The interepithelial lymphocytes of the intestinum, Morphological observations and immunologic aspects of intestinal enteropathy. Curr. Top. Pathol. 57 : 81-121, 1973.

2) Andrew, W.: Differentiation of migrant cells in the human epidermis and the nonspecificity of the germ-layers. Arch. Histol. Jpn. 29 : 211-235, 1968.

3) Silverberg, I. : Apposition of mononuclear cells to Langerhans cells in contact allergic reactions, an ultrastructural study. Acta Dermatovenerool. $53:$ 1-12, 1973.

4) Squier, C. A., Johnson, N. W. and Hackemann, M.: Structure and function of normal human oral mucosa. In Oral Mucosa in Health and Disease, ed. by Dolby, A. E., p. 1-95, Blackwell, Oxford, 1975.

5) Burkhardt, A. and Bos, I. R. : Ultrastrukurelle Beobachtungen an den interepithelialen Zellen der Mundschleimhaut. Verh. Dtsch. Ges. Pathol. 62 : 525, 1978.

6) Burkhardt, A., Bos, I. R., Löning, T., Gebbers, J., Otto, H. F. and Seifert,, G. : Interepithelial cells of the oral mucosa in mice, an ultrastructural classification with reflections on the origin of the Langerhans cells. Virchows Arch. A Path. Anat. Histol. 384 : 223-244, 1979.
7) Bos, I. R. and Burkhardt, A. : Interepithlial cells of the oral mucosa, light and electron microscopic observations in gremfree, specific pathogenfree and conventionalized mice. J. Oral Pathol. 9 : 65-81, 1980.

8) Bohle, A., Haussmann, P. and Vogt, W.: Über Beziehungen zwischen Lymphocyten und Harnkanälchenepithelien in der Niere des Menschen. Klin. Wschr. 48 : 1312-1326, 1970.

9) Toujas, L. and Guelfi, J. : Sur l'ultrastructure de la glande thyroide humaine. Z. Zellforsch. 94 : 118-128, 1969.

10) Ferguson, A. and Parrot, D. : The effect of antigen deprivation on thymun dependent and thymus independent lymphocytes in the small intestine of the mouse. Clin. Exp. Immunol. 12 : 477-488, 1972.

11) Otto, H.E. and Lewerenz, I. : Untersuchungen zur Ultrastruktur des Dünndarmes keinfrei aufgezofener FW 69-Ratten. I. Epitheliale Befunde unter besonderer Berücksichtigung der Paneth-Zellen. Virchows Arch. A Pathol. Anat. Histol. 360 : 235-251, 1973.

12) Guy-Grand, D., Griscelli, C. and Vasalli, P. : The gut associated lymphoid system, nature and properties of the large dividing cells. Eur. J. Immunol. 4 : 435-443, 1974.

13) Parrot, D. and Ferguson, A.: Selective migration of lymphocytes within the mouse small intestine. Immunol. 26 : 571-588, 1974. 